\title{
Singular Therapeutic Project in the management of complex cases: experience report in PEW-Health Interprofessionality
}

\section{Projeto Terapêutico Singular no manejo de casos complexos: relato de experiência no PET-Saúde Interprofissionalidade}

\author{
Maynara Guaripuna Ferreira' (D) $\mid$ mayguaripuna@gmail.com \\ Kathleen Hanna Gonçalves Ferreira1 (D) kathleenhanna73@gmail.com \\ Cibelle Regina Piani de Souza' (1) cibelle.piani@gmail.com \\ Priscila Cherley de Araújo Ortiz² (1) priscila.nutricionista@yahoo.com.br \\ Rodrigo Guimarães dos Santos Almeida' (D) rgclaretiano@gmail.com \\ Adélia Delfina da Motta Silva' (D) adelia.motta.silva@gmail.com
}

\begin{abstract}
Introduction: The Program Education through Work for Health (PEW-Health) was created in 2008 as a partnership between the Ministries of Health and Education, promoting the teaching-service-management-community integration, providing opportunities for professionals, students, teachers, and service users, in line with the needs of SUS, and having the topic of interprofessionality for its ninth edition (2019-2021). This report aims to share interprofessional learning based on the experience of a singular therapeutic project (STP) for a complex case within the PEW-Health activities of a university in the Midwest region, carried out in a Family Health Unit (FHU) in the municipality of Campo Grande, Mato Grosso do Sul (MS).

Experience report: Students from a tutorial group of PEW-Health Interprofessionality participated in this experience, as well as preceptors, professionals from the Extended Nucleus of Family Health and Primary Care (ENFH-PC), and a tutor, who was a teacher in a Medical School. The STP was developed with an elderly patient with polypharmacy and the following chronic conditions: diabetes mellitus (DM), depression (DEP) and systemic arterial hypertension (SAH), monitored during the period from August 2019 to February 2020, prior to the COVID-19 pandemic, in a FHU in Campo Grande-MS, selected by the team due to the complexity of the case.

Discussion: Through the STP, the group had the opportunity to evaluate, assist and perform practices to strengthen the patient's "happiness project". The STP allows team-patient intersubjectivity, focusing not only on the diseases, but on who they are. The carried-out home visits provided moments of listening for the performance of care in accordance with the needs, perceived and not perceived by the user. In the practice of STP, comprehensive care is provided, focused on the individual, showing the potential in continuing education and interprofessional teamwork, sharing knowledge, improving the sustainability of care and, consequently, qualifying health care, corroborating the results obtained in this study. Conclusion: Participation in the program allowed experiences that were previously absent during undergraduate school, such as contact with different health courses, practice in real SUS scenarios and application of concepts seen only in theory, such as humanized care and a comprehensive view, as well as communication with the team and the patient.
\end{abstract}

Keywords: Primary Health Care; Diabetes Mellitus; Diabetic foot; Hypertension; Patient-Centered Care.

\section{RESUMO}

Introdução: O Programa de Educação pelo Trabalho para a Saúde (PET-Saúde) surgiu em 2008, numa parceria entre o Ministério da Saúde e o Ministério da Educação, com o propósito de fomentar a integração ensino-serviço-gestão-comunidade e oportunizar vivências para profissionais, estudantes, professores e usuários dos serviços, em consonância com as necessidades do SUS. A nona edição (2019-2021) do programa teve como tema a interprofissionalidade. Este relato objetiva compartilhar a aprendizagem interprofissional a partir da experiência de um Projeto Terapêutico Singular (PTS) para um caso complexo dentro das atividades do PET-Saúde de uma universidade da Região Centro-Oeste, realizado em uma unidade de saúde da família (USF), em Campo Grande, em Mato Grosso do Sul (MS).

Relato de experiência: Participaram desta experiência acadêmicas de um grupo tutorial do PET-Saúde Interprofissionalidade, preceptoras, profissionais do Núcleo Ampliado de Saúde da Família e Atenção Primária (Nasf-AP), e tutora, docente de uma Faculdade de Medicina. O PTS foi desenvolvido com paciente idosa, com polifarmácia, com as seguintes condições crônicas: diabetes mellitus (DM), depressão (DEP) e hipertensão arterial sistêmica (HAS). A paciente foi acompanhada durante o período de agosto de 2019 a fevereiro de 2020, anterior à pandemia da Covid-19, em uma USF, em Campo GrandeMS, selecionada pela equipe em virtude da complexidade do caso.

Discussão: Por meio do PTS, o grupo teve a oportunidade de avaliar, auxiliar e executar práticas para fortalecer o "projeto de felicidade" da paciente. O PTS permite a intersubjetividade entre equipe e paciente, centrando-se não apenas nas doenças, mas também no indivíduo. As visitas domiciliares realizadas proporcionaram momentos de escuta para a condução do cuidado em conformidade às necessidades sentidas e não sentidas pela usuária. Na prática do PTS, presta-se cuidado integral, focado no indivíduo, de modo a apresentar as potencialidades na educação permanente e no trabalho em equipe interprofissional, compartilhar saberes, aprimorar a sustentabilidade do cuidado e, consequentemente, qualificar a assistência em saúde, corroborando os resultados obtidos nesta experiência.

Conclusão: A participação no programa permitiu vivências antes ausentes na graduação, como o contato com os diferentes cursos da saúde, a prática nos cenários reais do SUS e a aplicação dos conceitos vistos apenas na teoria, como o atendimento humanizado e olhar integral, além da comunicação com a equipe e paciente.

Palavras-chave: Atenção Primária à Saúde; Diabetes Mellitus; Pé Diabético; Hipertensão; Assistência Centrada no Paciente.

\footnotetext{
${ }^{1}$ Universidade Federal de Mato Grosso do Sul, Campo Grande, Mato Grosso do Sul, Brazil.

${ }^{2}$ Municipal Health Secretariat, Campo Grande, Mato Grosso do Sul, Brazil.
}

Chief Editor: Rosiane Viana Zuza Diniz. Associate editor: Ana Cláudia Santos Chazan.

Received on 09/21/21; Accepted on 12/07/21. | Evaluated by double blind review process. 


\section{INTRODUCTION}

Aiming to consolidate the doctrinal and organizational principles of the Brazilian Unified Health System (SUS, Sistema Único de Saúde), several movements have been carried out by the Ministries of Health and Education, over the years, aiming at integrating care, based on the intersectoriality of the professions since undergraduate school, encouraging the formation of professionals capable of teamwork and collaborative production, promoting interprofessionality, meeting the National Curriculum Guidelines (NCG) for courses in the health area ${ }^{1-5}$. However, the experience of interprofessionality during undergraduate school remains a challenge, considering the incompatibility of the curricula of health courses, the different practice scenarios, and the challenges of the teaching-service-management-community integration in SUS ${ }^{2,6}$.

From this perspective, the Education Program through Work for Health (PEW-Health) emerged in 2008, in partnership with the Ministries of Health and Education, aiming to promote the teaching-service-management-community integration, providing experience opportunities for professionals, students, teachers and service users, in line with the needs of SUS ${ }^{7}$, and having the topic of interprofessionality for its ninth edition (2019-2021), indicating the action plan defined for the implementation of changes in care practices, as established by the Pan-American Health Organization ${ }^{3,7}$.

Interprofessional Education (IPE) takes place when "students from two or more professions learn about each other, with others and between each other to allow an effective collaboration and improve health outcomes" (p. 10) ${ }^{8}$. This format seeks to integrate teaching-service through the participation of SUS workers, teachers, and students from different courses in the health area, together developing activities aimed at comprehensive care, at any level of health care ${ }^{2,3,5}$.

The proposition of the IPE is the transformation of health practices through the promotion of the collaboration between professionals and the learning of effective teamwork, advocating learning together to work together. Therefore, adopting the IPE assumptions aims to change health practices and generate interprofessional work in the context of SUS?.

While interprofessionality postulates collaborative interaction regarding the specific knowledge of each area, aiming to improve the quality of services and the type of care $^{10}$, multiprofessionality corroborates the fragmentation of care and the demarcation of knowledges ${ }^{11}$. It is understood, therefore, that interprofessionality converts the production of specific care into comprehensive care, promoting teamwork, integrating different professional centers in a collaborative way, focusing on the health needs of users and the population ${ }^{11}$.
In the context of interprofessionality, the Singular TherapeuticProject(STP), a device of the National Humanization Policy (NHP), emerges as a powerful tool for learning and care in Primary Health Care (PHC), considering the historicity and needs of the patient, becoming a care management tool in the transformation into the comprehensive care model, which aims at the production of autonomy, protagonism and social inclusion of the individual ${ }^{12-15}$.

The STP is presented as an instrument for organizing care, constructed between the team and the user, considering the individual's singularities and their complexity. Complex cases, frequent in $\mathrm{PHC}^{16}$, require complex solutions and reveal the need to consider cross-sectional issues in the production of care, comprising a set of proposals for therapeutic approaches, which require the articulation between different professionals and the use of team meetings to reflect on the case and possible solutions ${ }^{12,13,17}$. Thus, by requiring such articulation and collaborative teamwork, the STP gets closer to the IPE, enabling an effective collaboration between professionals and improvement in the comprehensive health care results ${ }^{11}$.

Therefore, this article aims to report the interprofessional learning based on the experience of structuring the STP for a complex case within the PEW-Health extension activities of Universidade Federal de Mato Grosso do Sul (UFMS) carried out in a Family Health Unit (FHU), in the municipality of Campo Grande, in the state of Mato Grosso do Sul (MS).

\section{EXPERIENCE REPORT}

Six students members of a tutorial group of PEWHealth Interprofessionality participated in this experience, who were from the following courses in the health area: Nursing, Pharmacy, Physiotherapy, Medicine, Dentistry and Psychology attending the second and third years of undergraduate school, female, aged between 19 and 22 years old; two preceptors, PHC professionals from the area of nutrition and physiotherapy, members of the Extended Nucleus of Family Health and Primary Care (ENFH-PC), and a tutor, a teacher at Faculdade de Medicina da UFMS, a dental surgeon. The STP was developed with a white, elderly, polypharmacy female patient, with the following chronic conditions: diabetes mellitus (DM), depression (DEP) and systemic arterial hypertension ( $\mathrm{SAH})$, monitored from August 2019 to February 2020, prior to the COVID-19 pandemic, in an FHU in Campo Grande-MS, selected by the team due to the complexity of the case.

The report of this experience was authorized by signing the free and informed consent form (FICF), being linked to the project "Interprofessionality from the perception of students, teachers, professionals and users of the Unified Health System", approved by Opinion N. 3,780,149 ( CAAE:2 
22845619.1.0000.0021) of the UFMS Ethics and Research Committee on studies in Human Beings.

The STP consisted of the following care movements and moments: choice of case, home visit, situational diagnosis, formulation of hypotheses for intervention, discussion of objectives by the team, definition of short, medium, and long-term goals, and after that, the reassessment of the case and results.

The case was chosen based on the topic of chronic conditions, and during the home visits, the conditions of life, housing, hygiene, health, social life, history, family relationships and morbidities were evaluated. The activities were directly monitored by the tutor and preceptors. The user had difficulties in adhering to treatment and conflicts with the FHU, in addition to coexisting chronic conditions. At the first meeting, the students, preceptors, and tutor were introduced and the reason for the visit was explained. Since the first moment, there was an approximation and greater knowledge was apprehended about the user's history in the SUS. The patient lives alone, in Campo Grande-MS, was born in São
Paulo-SP, is 68 years old, divorced, retired, has type II DM, SAH and PED, polypharmacy, non-smoker and non-alcoholic, and is literate. She had three pregnancies, two deliveries and a miscarriage, and has two daughters who live in another state, with whom she has a difficult and conflicted relationship. She reported a close relationship with her sister who lives in a municipality in the countryside. She also has a history of surgery on her left knee.

Following the STP steps, the diagnosis began with the evaluation and questions about the singularities, needs, social, economic, and biological factors, and the patient's desires, among others. Home visits took place weekly, proving to be fundamental for establishing the bond. At each contact, the patient reported the issues in greater depth and showed confidence in the team ${ }^{18}$.

Family approach tools, genogram and ecomap were used to propose strategies to be implemented in care (Figures 1 and 2). While the genogram produces a drawing of the family structure, representing kinship, family members' age,

Figure 1. Genogram of the reported case, built using the "Family Album" tool of the Center for Education in Collective Health (Nescon) at UFMG. Campo Grande/MS - 2020.

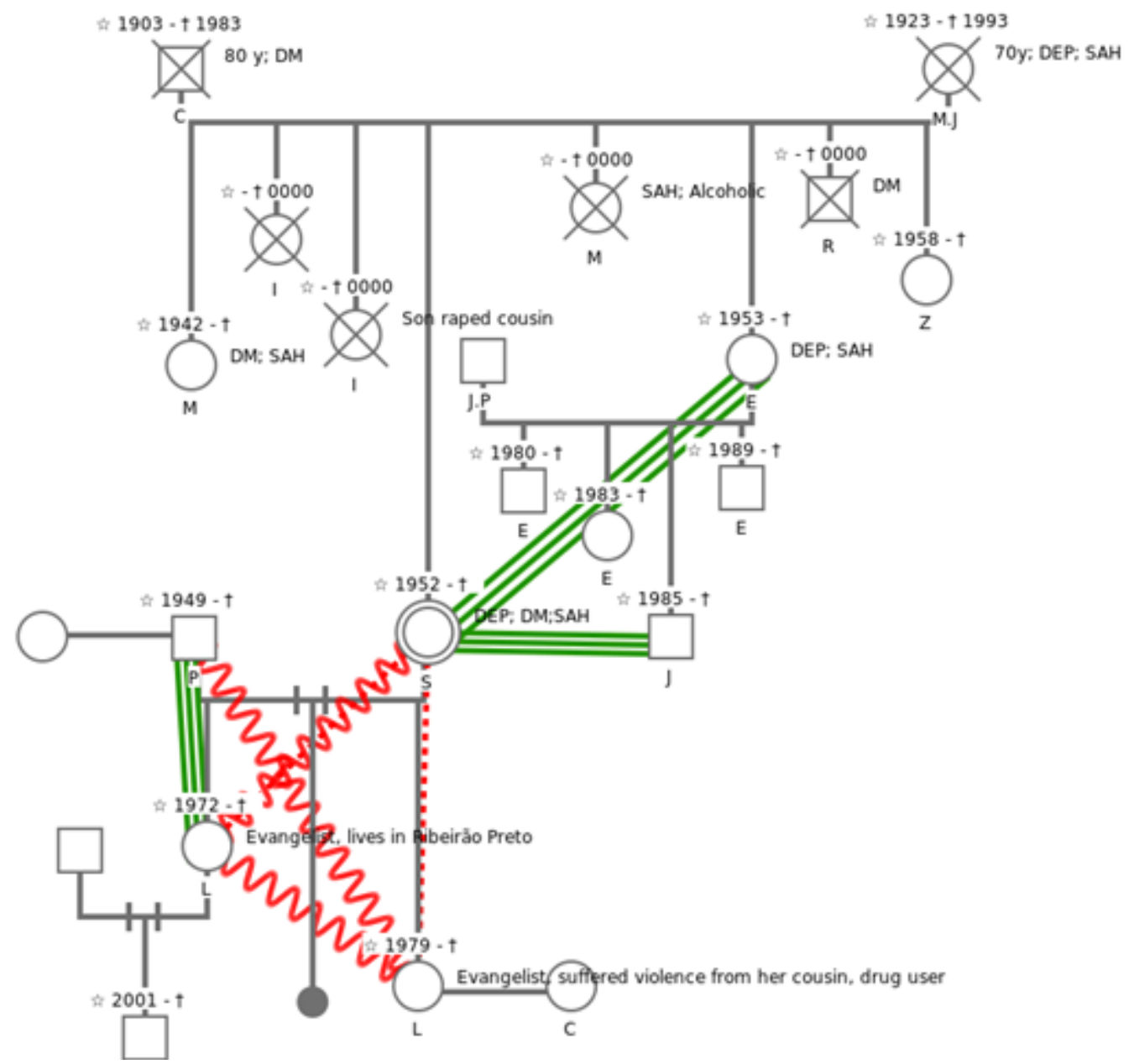

Software abbreviations: $\mathrm{y}=$ years. $\mathrm{DEP}=$ depression. $\mathrm{DM}=$ diabetes mellitus. $\mathrm{SAH}=$ systemic arterial hypertension. Source: created by the authors. 
Figure 2. Ecomap constructed using the CANVA application, together with the patient. Campo Grande/MS - 2020.

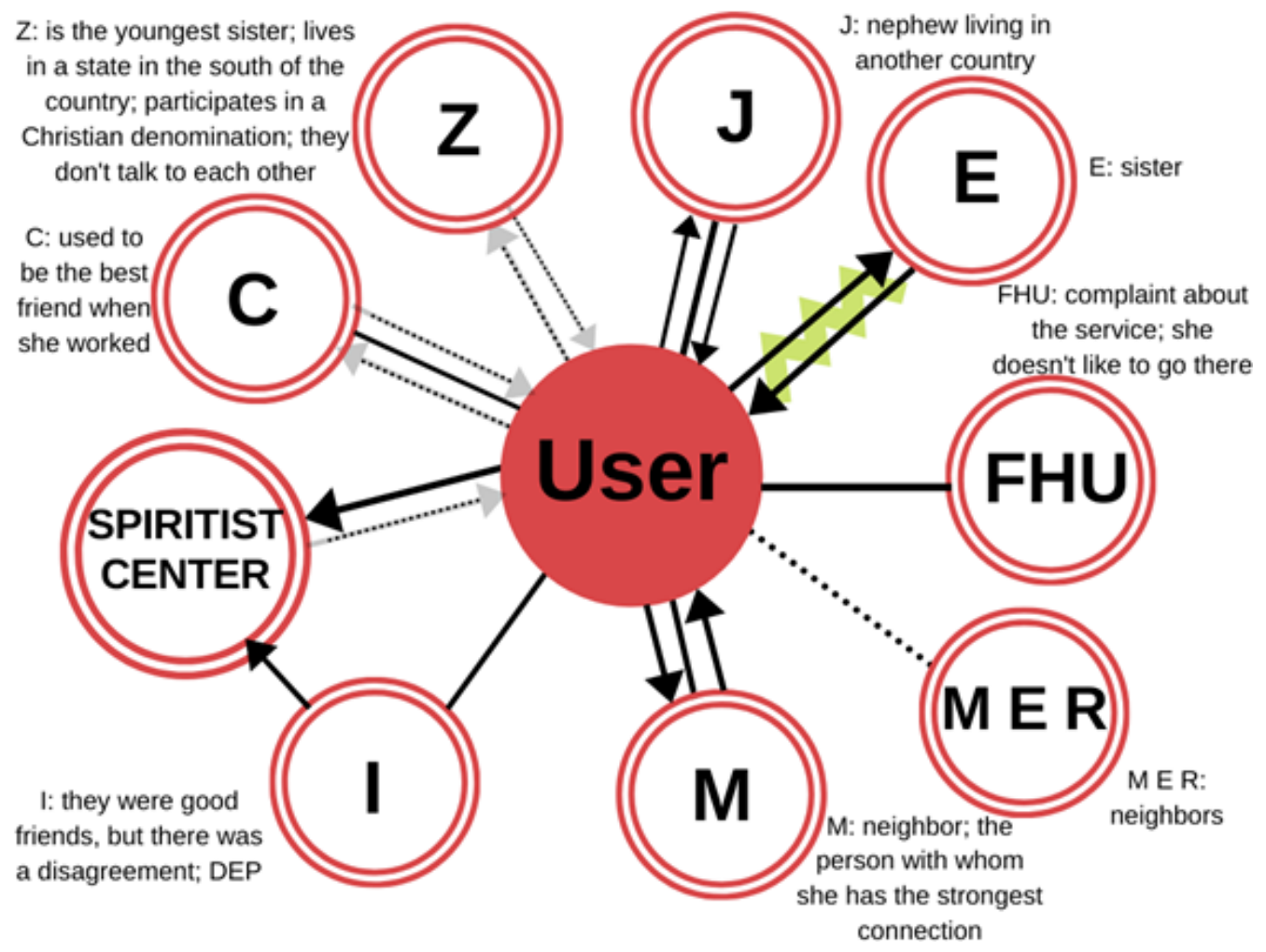

Abbreviations: $\mathrm{DEP}=$ depression; $\mathrm{FHU}=$ family health unit.

Source: created by the authors.

diseases, risk factors and the complexity of family relationships, the ecomap allows family assessment, complementary to the genogram, which includes other affective ties associated with the individual, connecting people and families to the social support networks necessary to produce care ${ }^{13,19,20}$.

These instruments were built with manual sketches as the information was being reported. Subsequently, the genogram was designed using the "Family Album" tool of the Center for Education in Collective Health (Nescon, Núcleo de Educação em Saúde Coletiva) of the Universidade Federal de Minas Gerais ${ }^{19,21}$. For the ecomap, the graphic design platform Canva $^{22}$ was used.

When using these tools, the group observed the repetition of illness patterns, the patient's family nucleus, thus having a better perception of the social context. They helped to establish relevant goals and identify possible sources of social support ${ }^{20,23}$. The ecomap showed the patient's vulnerabilities, since the people with whom she had the strongest relationships were physically distant from her, except for her neighbor $M$, with whom she had a stronger bond, albeit, also a conflicting one.

The evaluation of the diabetic foot was also carried out, following the recommendations of the Basic Care Notebook: Strategies for the care of people with chronic disease: diabetes mellitus (Estratégias para o cuidado da pessoa com doença crônica: diabetes mellitus) ${ }^{24}$, with inspection of the skin, nails and toes; checking for bone deformities; measurement of the posterior tibial and pedal pulse; sensitivity test with monofilament and tuning fork (vibrating sensitivity) and the aquileus reflex. Interdigital mycoses, claw toes, changes in skin color and temperature, loss of sensitivity, cracks and tingling were detected, classifying as Grade 2 in the risk category ${ }^{18}$, which corresponds to peripheral arterial disease (PAD) with or without loss of protective sensation (LPS).

The definition of short, medium, and long-term goals that were negotiated with the user respected the principles proposed for the STP ${ }^{13,25}$. The first goal was to improve the condition of the diabetic foot, through actions such as adequate nail clipping, skin hydration, advice on adequate footwear and kinesiotherapy, aiming at improving peripheral vascularization $^{26-28}$.

It was also necessary to address the issue of polypharmacy which, according to Mangin et al. ${ }^{29}$, can be considered real risks to the good health of the elderly and, above all, those with comorbidities. It is noteworthy that complex drug regimens tend to exceed the patient's ability to manage, reducing adherence, especially among the elderly, which we verified in practice with the patient, who was not able to adequately organize, alone, the intake of the different prescribed drugs. Although the group had difficulties in changing the prescription, as the team who cared for the user 
Figure 3. First care actions for the rational use of medications: prescription review; reorganization of the patient's medication box, with the removal of expired drugs. Campo Grande/MS - 2020.

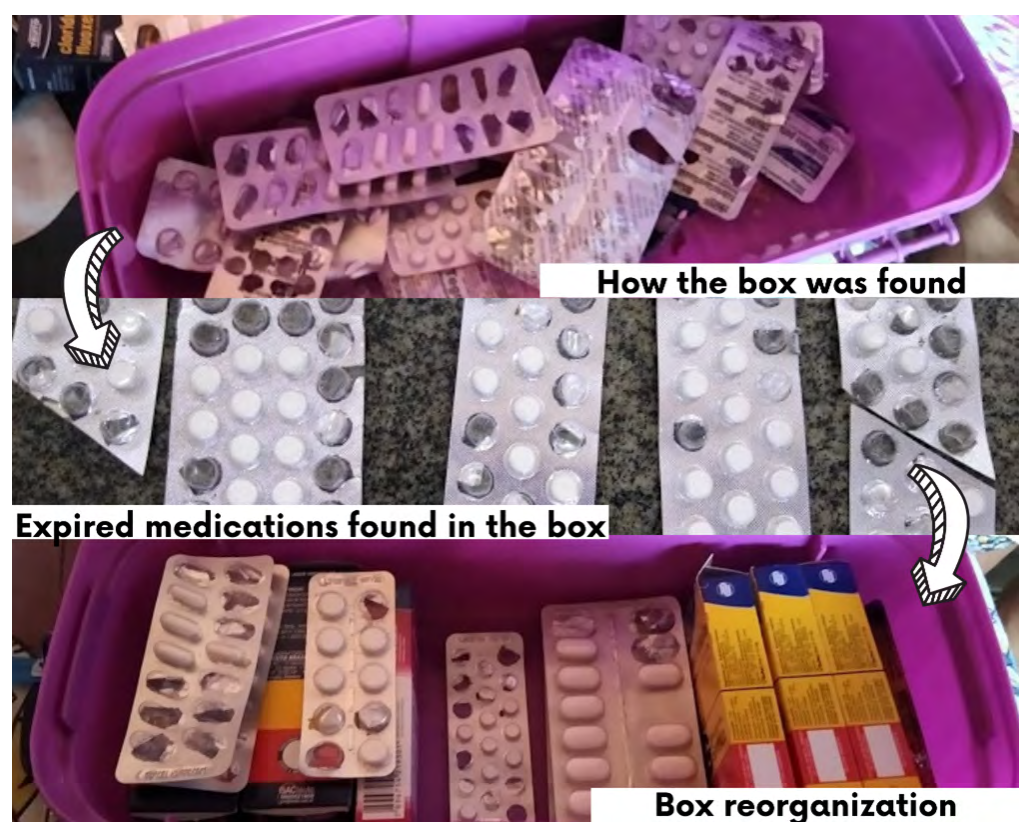

Source: created by the authors.

did not include a physician, by reorganizing the medication box (Figures 3 and 4) and creating a form to schedule intakes and alarms at the correct times, we sought to ensure the rational use of medications, while considering issues such as loneliness and social isolation, giving voice to the needs felt by the patient, actions that are as important as the prescription ${ }^{29}$.

Prescription intervention occurred due to reports of inadequacy of use, difficulty understanding the prescription and expired medication. At first, the patient's medication "box" was reorganized (Figure 3). Another strategy was to contact the FHU to schedule an appointment with the only doctor available in the unit, from another team, in order to update the prescriptions. Subsequently, a table was provided with the names of the drugs and stipulated times. In addition, the students made a box with divisions (Figure 4) for the patient to store the medications correctly, separating them while using the same colors that were included in the table, in addition to providing the correct disposal of expired drugs. Considering the different medication intake times, the students programmed the patient's cell phone with reminders (alarms) at these times.

Following the logic of building happiness projects ${ }^{30,31}$, dreams of resocialization were rescued, as it was shared with the group that her great desire was to return to the university, since she had not been able to graduate due to payment difficulties. An initial resocialization opportunity was the incentive to participate in physical activity groups promoted by the ENFH-PC at the FHU, allowing the reestablishment of
Figure 4. After searching for alternatives, a new medicine box was created by the students. Campo Grande/MS 2020.

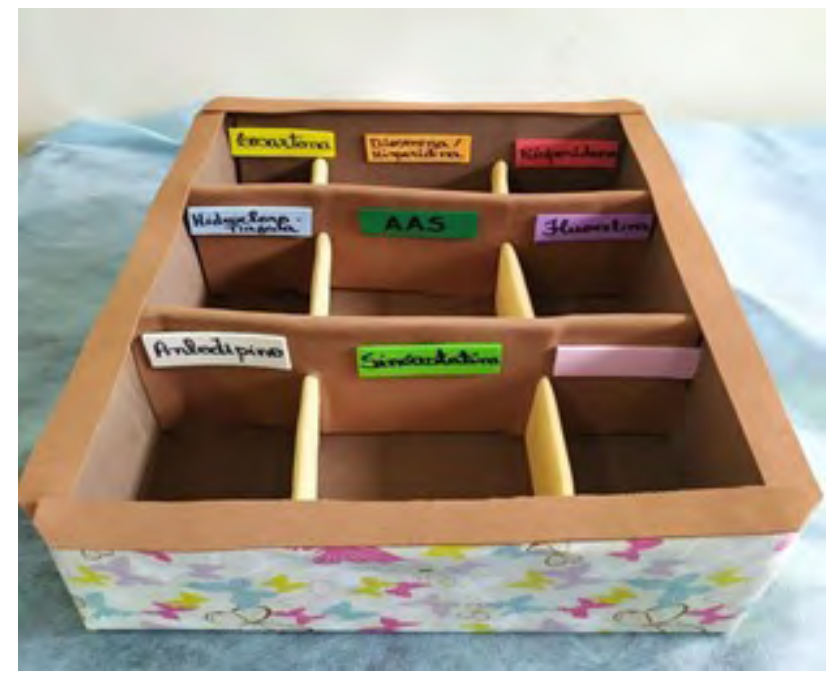

Source: created by the authors.

the bond with the unit. In the medium term, her inclusion in the Institutional Program of the Open University to the Elderly (Universidade Aberta à Pessoa Idosa) (UnAPI/UFMS) was sought, with weekly participations in the "MemorIDADE" memory workshop, in which cognitive and psychosocial stimulation activities are developed, based on the concept of lifelong learning ${ }^{32}$.

Moreover, personalized health education actions were developed. It is noteworthy the dynamics for understanding 
chronic conditions and consequences for the body. For this purpose, the Conversation Map "How the Body and Diabetes Work" (Como o Corpo e a Diabetes Funcionam) ${ }^{33}$ was used, which is an educational strategy with interactive illustrations about everyday situations faced by people living with $\mathrm{DM}^{34}$. Other covered topics included healthy eating, diabetic foot care and women's health.

At each stage of the process, the STP form was updated with procedures and information. The division of responsibilities took place during the team's meetings and discussions about the case, as well as during the home visits, respecting the patient's role and ability to accept changes. Furthermore, following the reassessment process, the procedures that were performed at the diagnosis stage were reapplied. Through re-examinations, conversations, attitudes, and reports, both from the user and members of the FHU team, the evolution of the case was observed, especially in relation to the diabetic foot (Figure 5).

It is worth mentioning that the tools used in PHC promoted the exchange of knowledges between the different trainings of the students and professionals, who understood the difference between common, specific, and collaborative practices and, thus, recognized the possibility of exchanging knowledges based on devices such as the STP. The evaluation of this practice took place collectively and procedurally by the participants, with the tutor having the role of the trigger of this process that, at the end, was shared with the user, with her perception being verbalized.

\section{DISCUSSION}

In contrast to conventional care models, which focus on curative, specialized, fragmented and individual care, the ENFH-PC work proposal is to overcome this logic towards the co-responsibility and integrated care management through shared care and therapeutic projects that involve users in $\mathrm{PHC}$, being able to consider the uniqueness of the individuals ${ }^{35}$, which was experienced in practice by the group. Considering the methodological proposal of the nucleus for interdisciplinary and interprofessional work, it is necessary to critically review the educational and training processes that have been made available by Higher Education Institutions in the training of professionals in the health area ${ }^{13,35}$, since interprofessional work, in fact, has not been routinely provided in undergraduate courses - neither in practice, nor in the pedagogical projects of the courses (PPC) ${ }^{11}$ - with PEW-Health constituting an opportunity, albeit in an extension format, for such learning.

Therefore, it is noteworthy that, through the STP, the group had the opportunity to evaluate, assist and perform practices, aiming to strengthening the patient's "happiness project" ${ }^{\prime 30,31}$, developing common and complementary skills as well as collaborative dimensions of the $\mathrm{IPE}^{36}$, and learning about comprehensive care for people with chronic conditions ${ }^{6,10,27}$. The STP allows team-patient intersubjectivity, focusing not only on the diseases, but on who the patient is. Happiness can be understood with a value that is structured from real and necessary experiences to live, making the individual aware of their own experiences and exchanges established with other individuals, and it is important that the agents promoting

Figure 5. Evolution of the diabetic foot care. Campo Grande/MS - 2020.
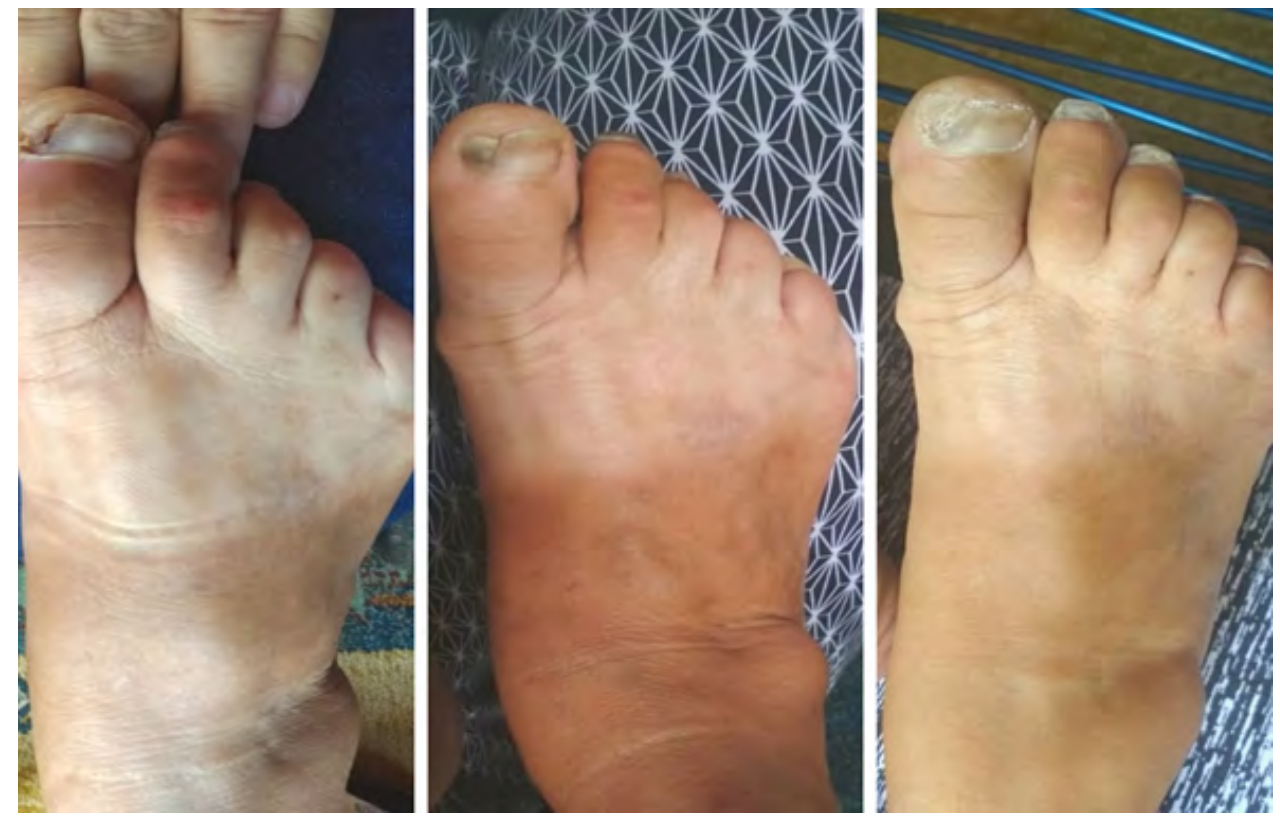

Source: created by the authors. 
health practices be more attentive and flexible regarding the user's desires, by listening, sharing experiences and purposes, aiming to establish a bond through dialogue ${ }^{31}$.

During the semester, the group was challenged to think about and care for the patient, listening to her demands, recognizing her "happy project, that is, what conception of successful life $\mathrm{I}^{\prime 37}$ (p.68) guided the life of that woman being cared by them. During this process, it can be said that the group had the opportunity to learn about caring in a humanized way, opening space for dialogue in all therapeutic encounters, accepting and sharing responsibilities, rebuilding identities ${ }^{30,31}$.

Based on the completion of this STP, over time and through effective and affective communication with the group, the patient shared her anxieties and ambitions, stories, her physical and psychological scars, allowing a more precise intervention by the team. The home visits provided moments of attention and listening to conduct the care in accordance with the needs, perceived and not perceived by the user ${ }^{38}$.

The foundation and importance of care in health actions occurs through the promotion of attitudes that induce intersubjective encounters, aided by technologies but not restricted to them, aiming at the humanization of care $^{37}$. Macedo et al. ${ }^{39}$ corroborate this experience by concluding that there are extrinsic and intrinsic configurations that encompass the human being, involving social, cultural, and personal aspects, being necessary to detect the most pertinent of each circumstance, important guides for the necessary intervention, being aware that it is a dynamic process that requires differentiated care at each moment. In turn, Mendes et al. ${ }^{40}$ report efficiency in STP practice, providing comprehensive care, focused on the individual, showing potential in continuing education and interprofessional teamwork, sharing knowledges among the team members, improving the sustainability of care and, consequently, improving health care, corroborating the results obtained in this experience.

The experience reported herein reinforces the guidelines given by the National Health Council in its Resolution n. 569, of December 8, 2017², which point to interprofessional work as a guide for the NCG of courses in the health area, so that teamwork is effective in practice promoting the integrality of both the different cores of professional knowledge, as well as care and intersectoriality, integrating different sectors of society to solve complex situations of health needs, also stimulating the creation of STP based on interprofessional and collaborative logic. Moreover, the contact with tools such as the genogram, ecomap and the STP itself allowed experiences that were previously absent in undergraduate studies. Thus, this PEW-Health experience showed that the inclusion of such principles in PPC is viable, aiming to promote changes in the training of professionals and, consequently, in the production of health care.

Regarding the fact that the PEW-Health is a macro-policy that triggers IPE in health education, its potential is perceived. However, it is a particular policy that needs to be incorporated by educational institutions, in PPCs in the health area, to reverse the uniprofessional, curative and hospital-centric logic that permeates society.

The PEW-Health project, in its entirety, at UFMS, had the participation of about 87 students (scholarship fellows and volunteers), 20 preceptors and 10 tutors who provided care in PHC in seven health units in the capital of Mato Grosso do Sul, contributing to improve the quality of life of SUS users, especially in the context of health promotion and disease prevention, making the IPE experience the channel for the development of interprofessionality and key to meet the needs of the health sector and the job market.

\section{FINAL CONSIDERATIONS}

The experience of using IPE, of experiencing interprofessionality, learning of and with others, of exercising comprehensive care and collaborative practices, made it possible to change the patient's quality of life, in addition to providing learning about interprofessional work for future health workers, facing the challenges of care for chronic conditions.

Finally, participation in the PEW-Health project allowed new experiences in undergraduate courses, such as contact with different health courses, practice in real-life scenarios of the SUS and application of concepts seen only in theory, such as humanized care, comprehensive view and communication with the team and the patient. Despite the limited number of patients that were reached, the program also allowed the recognition of users - from the constructed and performed STP- as protagonists and co-producers of health care, shifting the center of care from the disease to the person. It was recognized that training in the SUS and for the SUS cannot be performed without meeting people's health needs, as well as comprehensive care, training workers to organize interprofessional teamwork, committed to the population's health reality.

\section{AUTHORS' CONTRIBUTION}

Maynara Guaripuna Ferreira, Kathleen Hanna Gonçalves Ferreira, Priscila Cherley de Araújo Ortiz, and Adélia Delfina da Motta Silva participated in the development of the singular therapeutic project that originated the report. Maynara Guaripuna Ferreira, Cibelle Regina Piani de Souza and Adélia Delfina da Motta Silva participated in the investigation. Maynara Guaripuna Ferreira, Kathleen Hanna Gonçalves Ferreira, Cibelle Regina Piani de Souza and Adélia Delfina da Motta Silva 
participated in the original drafting of the manuscript. Rodrigo Guimarães dos Santos Almeida contributed with the writing of the manuscript - reviewing and editing. Adélia Delfina da Motta Silva contributed with supervision, conceptualization, methodology and resources.

\section{CONFLICTS OF INTEREST}

The authors declare no conflicts of interest.

\section{SOURCES OF FUNDING}

Experience associated to Public Notice n. 10, July 23, 2018, selection for Programa de Educação pelo Trabalho para a Saúde PET-Saúde/Interprofissionalidade, project 51.

\section{REFERENCES}

1. Brasil. Portaria Interministerial no 1.127 , de 4 de agosto de 2015. Institui as diretrizes para a celebração dos Contratos Organizativos de Ação Pública Ensino-Saúde (COAPES), para o fortalecimento da integração entre ensino, serviços e comunidade no âmbito do Sistema Único de Saúde (SUS). Brasília: Ministério da Saúde, Ministério da Educação; 2015 [acesso em $1^{\circ}$ abr 2021]. Disponível em: https://www.uff.br/icvgv/files/2017/06/2.Portaria-Interministerial-N\%c2\%ba-1.127-DE-04-de-Agosto-de-2015.pdf.

2. Brasil. Conselho Nacional de Saúde. Resolução n 569 , de 8 de dezembro de 2017. Brasília: Ministério da Saúde; 2017 [acesso em 31 mar 2021]. Disponível em: http://conselho.saude.gov.br/resolucoes/2017/Reso569.pdf.

3. Brasil. Edital no 10, de 23 de julho 2018 - Seleção para o Programa de Educação pelo Trabalho para a Saúde PET-Saúde/Interprofissionalidade 2018/2019. Diário Oficial da União; 24 jul 2018. Seção 3, p. 78-81.

4. Brasil. Constituição da República Federativa do Brasil: texto constitucional promulgado em 5 de outubro de 1988, compilado até a Emenda Constitucional n 105/2019. Brasília: Senado Federal, Coordenação de Edições Técnicas; 2020, p. 397.

5. Castro FS, Cardoso AM, Penna KGBD. As Diretrizes Curriculares Nacionais dos cursos de graduação da área da saúde abordam as políticas públicas e o sistema único de saúde? Revista Brasileira Militar de Ciências. 2019;5(12):29-34. doi: 10.36414/rbmc.v5i12.11.

6. Batista, NA. Educação interprofissional em saúde: concepções e práticas. Caderno FNEPAS. 2012;2:25-8 [acesso em 14 fev 2020]. Disponível em: https:// edisciplinas.usp.br/pluginfile.php/4298824/mod_resource/content/1/ educacao_interprofissional.pdf.

7. Brasil. Portaria interministerial no 1.802 , de 26 de agosto de 2008. Institui o Programa de Educação pelo Trabalho para a Saúde - PET-Saúde. Brasília: Ministério da Saúde, Ministério da Educação; 2008 [acesso em 20 maio 2021]. Disponível em: https://bvsms.saude.gov.br/bvs/saudelegis/ gm/2008/pri1802_26_08_2008.html.

8. Organização Mundial da Saúde. Marco para ação em educação interprofissional e prática colaborativa. Genebra: OMS; 2010 [acesso em 18 fev 2020]. Disponível em: https://www.educacioninterprofesional.org/pt/ marco-para-acao-em-educacao-interprofissional-e-pratica-colaborativa.

9. Ogata MN, Silva JAM, Peduzzi M, Costa MV, Fortuna CM, Feliciano $A B$. Interfaces between permanent education and interprofessional education in health. Rev Esc Enferm USP. 2021;55:e03733. doi: 10.1590/ S1980-220X2020018903733.

10. Olson R, Bialocerkowski A. Interprofessional education in allied health: a systematic review. Med Educ. 2014;48(3):236-46. doi: 10.1111/ medu.12290.

11. Peduzzi M, Norman IJ, Germani ACCG, da Silva JAM, de Souza GC Interprofessional education: training for healthcare professionals for teamwork focusing on users. Rev Esc Enferm USP. 2013;47(4):977-83. doi: 10.1590/S0080-623420130000400029.
12. Brasil. Diretrizes do Nasf: Núcleo de Apoio à Saúde da Família. Brasília: Ministério da Saúde; 2010. (Caderno de Atenção Básica, n²7).

13. Brasil. Núcleo de Apoio à Saúde da Família. Brasília: Ministério da Saúde, 2014. (Cadernos de Atenção Básica, no 39).

14. Hori AA, Nascimento AF. O Projeto Terapêutico Singular e as práticas de saúde mental nos Núcleos de Apoio à Saúde da Família (Nasf) em Guarulhos (SP). Brasil. Ciênc Saúde Colet. 2014;19(8):3561-71. doi: 10.1590/1413-81232014198.11412013.

15. Melo EA, Vianna EC, Pereira LA, organizadores. Caderno do curso Apoio Matricial na Atenção Básica com Ênfase nos Nasf: aperfeiçoamento. 2a ed. Rio de Janeiro: EAD, Ensp, Fiocruz; 2016 [acesso em 14 fev 2020]. Disponível em: https://ead.saude.pe.gov.br/pluginfile.php/3897/mod_ folder/content/0/caderno-curso-nasf.pdf?forcedownload=1.

16. Reis RC, de Souza ARND, Favoreto CAO. Casos complexos na atenção primária à saúde: narrativas de residentes em Medicina de Família e Comunidade. Anais do Congresso Brasileiro de Saúde Coletiva; 2018; Rio de Janeiro. Campinas: Galoá; 2018 [acesso em 31 mar 2021]. Disponível em: https://proceedings. science/saude-coletiva-2018/papers/casos-complexos-na-atencao-primariaa-saude--narrativas-de-residentes-em-medicina-de-familia-e-comunidade.

17. Castro Filho ED, Gusso GDF, Demarzo MMP, Stein A, Schneider JC, Dalla MDB, et al. A especialização em MFC e o desafio da qualificação médica para a Estratégia Saúde da Família: proposta de especialização, em larga escala, via educação à distância. Rev Bras Med Fam Comunidade. 2007;3(9):199-20 [acesso em 12 maio 2021]. Disponível em: https://rbmfc. org.br/rbmfc/article/view/338.

18. Ferreira MG, Ferreira KHG, Ortiz PCA, Silva ADM. PET-Saúde Interprofissionalidade: aprendizagens no uso do projeto terapêutico singular. Saúde e Meio Ambiente: Revista Interdisciplinar. 2020;9(supl1):7980 [acesso em 14 maio 2021]. Disponível em: http://www.periodicos.unc. br/index.php/sma/article/view/3403.

19. Chapadeiro CA, Andrade HYSO, de Araújo MRN, organizadores. A família como foco da atenção básica à saúde. Belo Horizonte: Nescon, UFMG; 2012 [acesso em 3 abr 2021]. Disponível em: https://www.nescon.medicina. ufmg.br/biblioteca/imagem/3911.pdf.

20. Dias LC. Abordagem familiar. In: Gusso G, Lopes JMC, Dias LC. Tratado de medicina de família e comunidade: princípios, formação e prática. 2a ed. Porto Alegre: Artmed, 2019.

21. Universidade Federal de Minas Gerais. Projeto Álbum de Família. Belo Horizonte: UFMG; 2011 [acesso em 3 abr 2021]. Disponível em: https:// www.nescon.medicina.ufmg.br/genograma/.

22. Perkins $\mathrm{M}$, Obrecht C, Adams C. Canva: design gráfico para todos. 2012 [acesso em 30 mar 2020]. Disponível em: https://www.canva.com.

23. Libbon R, Triana J, Heru A, Berman E. Family skills for the resident toolbox: the 10-min genogram, ecomap, and prescribing homework. Acad Psychiatry. 2019;43(4):435-9 [acesso em 10 abr 2021]. doi: 10.1007/ s40596-019-01054-6.

24. Brasil. Estratégias para o cuidado da pessoa com doença crônica: diabetes mellitus. Brasília: Ministério da Saúde, 2013. (Cadernos de Atenção Básica, nº 36).

25. Brasil. Clínica ampliada, equipe de referência e projeto terapêutico singular 2a ed. Brasília: Ministério da Saúde; 2007 [acesso em 15 fev 2020]. Disponível em: http://bvsms.saude.gov.br/bvs/publicacoes/clinica_ampliada_2ed.pdf.

26. Brasil. Manual do pé diabético: estratégias para o cuidado da pessoa com doença crônica. Brasília: Ministério da Saúde, 2016.

27. Mishra SC, Chhatbar KC, Kashikar A, Mehndiratta A. Diabetic foot. BMJ. 2017;16(359):j5064 [acesso em 11 abr 2021]. doi: 10.1136/bmj.j5064.

28. Nather A, Cao S, Chen JLW, Low AY. Prevention of diabetic foot complications. Singapore Med J. 2018;59(6):291-4. doi: 10.11622/smedj.2018069.

29. Mangin D, Heath I. Multimorbidade e prevenção quaternária (P4). Rev Bras Med Fam Comunidade. 2015;10(35):1-5 [acesso em 20 maio 2021]. Disponível em: https://rbmfc.org.br/rbmfc/article/view/1069.

30. Ayres JRCM. Sujeito, intersubjetividade e práticas de saúde. Ciênc Saúde Colet. 2001;6(1):63-72. doi: 10.1590/S1413-81232001000100005.

31. Ayres JRCM. Uma concepção hermenêutica de saúde. Physis. 2007;17(1):43-62. doi: 10.1590/\$0103-73312007000100004. 
32. dos Santos DG, Seixas RAM, Luchesi BM. Avaliação dos impactos promovidos pela oficina de memória "MemorlDADE" para idosos da UnAPI/UFMS. Anais do Integra UFMS; 2020; Campo Grande [acesso em 31 mar 2021]. Disponível em: https://integra.ufms.br/files/2021/01/ Anais_2020_Final.pdf.

33. Healthy Interactions. Programs catalog. Chicago: Healthy Interactions; 2015[acesso em 18 fev 2020]. Disponível em: https://www. healthyinteractions.com/assets/files/HI_Catalog_v01_09_093015.pdf.

34. de Carvalho SL, Ferreira MA, Medeiros JMP, Queiroga ACF, Moreira TR, Silva NFDS. Mapa de conversação: estratégia educativa no cuidado ao idoso com diabetes mellitus. Rev Bras Enferm. 2018;71(supl 2):925-9. doi: 10.1590/0034-7167-2017-0064.

35. dos Anjos KF, Sacramento MS, Ferraz CEO, Vilela ABA, Boery RNSO, Sena ELS. Perspectivas e desafios do núcleo de apoio à saúde da família quanto às práticas em saúde. Saúde Debate. 2013;37(99):672-80. doi: 10.1590/ S0103-11042013000400015.

36. Barr H. Competent to collaborate: towards a competency-based model for interprofessional education. J Interprof Care. 1998;12(2):181-7. doi: doi:10.3109/13561829809014104.
37. Deslandes SF, organizadora. Humanização dos cuidados em saúde: conceitos, dilemas e práticas. Rio de Janeiro: Fiocruz; 2006. doi: 10.7476/9788575413296.

38. Dorigatti AE, Aguilar ML, Madureira RM, da Fonseca FG, Campos RTO, Nascimento JL. Projeto terapêutico singular no âmbito da saúde mental: uma experiência no curso de graduação em medicina. Rev Bras Educ Med. 2014;38(1):113-9. doi: 10.1590/S0100-55022014000100015.

39. Macedo CS, Brandão ICA, Leal JAD, de Oliveira Júnior LG, Cortez RL, Honório MLP, et al. Elaboração de um projeto terapêutico singular para uma família de alto risco em uma unidade básica de saúde, MacaíbaRN: relato de experiência. Revista Eletrônica Extensão \& Sociedade. 2017;6(1):51-66 [acesso em 15 fev 2020]. Disponível em: http://repositorio. ufc.br/bitstream/riufc/35615/1/2017_art_csmacedo.pdf.

40. Mendes KMC, Veloso RV, Teixeira DMT, Banfi MB, da Costa BC, Sousa GV, et al. O uso do Projeto Terapêutico Singular como estratégia para o trabalho interprofissional na atenção pPrimária à saúde: um relato de experiência do Pet Saúde Interprofissionalidade. Enfermagem: Processos, Práticas e Recursos. 2021;(24)236-42. doi: 10.22533/AT.ED.24021240224. 